\title{
The Importance of Asphodeline Species on Enzyme Inhibition: Anti-Elastase, Anti-Hyaluronidase and Anti-Collagenase Potential
}

\author{
Asphodeline Türlerinin Enzim İnhibisyonundaki Önemi: Anti-Elastaz, \\ Anti-Hyalüronidaz ve Anti-Kollajenaz Potansiyeli
}

Mert İLHAN1, Gökhan ZENGIN², Esra KÜPELI AKKOL1, Abdurrahman AKTÜMSEK2, İpek SÜNTAR1*

${ }^{1}$ Gazi University, Faculty of Pharmacy, Department of Pharmacognosy, 06330 Ankara, TURKEY

2Selçuk University, Faculty of Science, Department of Biology, 42250 Konya, TURKEY

\begin{abstract}
Asphodeline species are widespread in the inner Anatolia region in Turkey and used for the treatment of skin disorders, earaches and haemorrhoids. The aim of the present study is to investigate in vitro inhibitory effects of the extracts prepared from the stems, seeds, leaves and roots of Asphodeline brevicaulis subsp. brevicaulis var. brevicaulis, A. baytopae and A. cilicica on hyaluronidase, collagenase and elastase enzymes. Hyaluronidase, collagenase and elastase inhibitory effects of the extracts were performed by using in vitro enzyme inhibitory assays based on spectrophotometric evaluation. The methanol extract of the roots of $A$. cilicica displayed the highest hyaluronidase, collagenase and elastase inhibitory activities. On the other hand, the acetone extract of the roots of $A$. cilicica, the acetone extract of the leaves of $A$. brevicaulis subsp. brevicaulis var. brevicaulis, the acetone and the methanol extracts of seeds of $A$. baytopae, acetone and the methanol extract of the roots of A. baytopae, the aqueous extract of the stems of $A$. cilicica, the acetone and the methanol extracts of the leaves of $A$. cilicica, the aqueous extract of the roots of $A$. cilicica possessed significant collagenase, hyaluronidase and elastase inhibitory activities. In the present study, extracts of Asphodeline species significantly inhibited collagenase, elastase and hyaluronidase enzymes, suggesting their utilization for the treatment of wounds, cancer, cardiovascular diseases, inflammation, bone destruction and fibrosis, as well as skin aging.
\end{abstract}

Key words: Asphodeline, Xanthorrhoeaceae, Collagenase, Elastase, Hyaluronidase

\section{öz}

Asphodeline türleri Türkiye'de İç Anadolu Bölgesi'nde geniş bir yayılış göstermektedir ve halk arasında deri hastalıkları, kulak ağrıları ve hemoroit gibi rahatsızlıklara karșı kullanılmaktadır. Bu çalıșmanın amacı, Asphodeline brevicaulis subsp. brevicaulis var. brevicaulis, A. baytopae ve A. cilicica bitkilerinin gövde, tohum, yaprak ve köklerinden hazırlanan ekstrelerin hyalüronidaz, kollajenaz ve elastaz enzimleri üzerindeki in vitro inhibitor etkinliklerini araştırmaktır. Bu ekstrelerin inhibitor etkileri spektrofotometrik yöntemlerle değerlendirilmiștir. A. cilicica köklerinden hazırlanan metanol ekstresinin en yüksek hyalüronidaz, kollajenaz ve elastaz inhibitor aktivitelere sahip olduğu belirlenmiştir. Diğer yandan, $A$. cilicica köklerinden hazırlanan aseton ekstresinin, A. brevicaulis subsp. brevicaulis var. brevicaulis yapraklarından hazırlanan aseton ekstresinin, $A$. baytopae köklerinden ve tohumlarından hazırlanan aseton ve metanol ekstrelerinin, $A$. cilicica gövdesinden hazırlanan sulu ekstrenin, $A$. cilicica yapraklarından hazırlanan aseton ve metanol ekstrelerinin, $A$. cilicica köklerinden hazırlanan sulu ekstrenin önemli ölçüde kollajenaz, elastaz ve hyalüronidaz etki gösterdiği belirlenmiştir. Sonuç olarak bu çalışmada Asphodeline türlerinden hazırlanan ekstrelerin kollajenaz, elastaz ve hyalüronidaz enzimlerini önemli ölçüde inhibe ettiği ortaya koyulmuştur. Bu nedenle bu sonuçlar bitkinin yara, kanser, kardiyovasküler rahatsızlıklar, enflamasyon, kemik yıkımı ve fibrozis gibi hastalıkların tedavisinde kullanılabileceğini destekler niteliktedir.

Anahtar kelimeler: Asphodeline, Xanthorrhoeaceae, Kollajenaz, Elastaz, Hyalüronidaz

\section{INTRODUCTION}

Asphodeline Rchb. genus (Xanthorrhoeaceae), represented by 14 species in the world, is growing wild in south-west Asia and Middle-Eastern countries as well as in Mediterranean region. In Turkey, Asphodeline genus comprises of 20 taxa, 12 of which are endemic to Turkey showing that Turkey is one of the gene centres of this genus (1-3). In rural areas in Turkey, several Asphodeline species are known in the name of "çiriş" and are widespread in inner Anatolia region. Especially Asphodeline cilicica E. Tuzlacı, A. damascena (Boiss.) Baker, A. globifera J. Gay Ex Baker, A. lutea (L.) Rchb. and A. taurica (Pallas) Kunth are consumed as food in salads (4). This genus 
was recorded to have economical and nutritional importance with high levels of essential amino acids and polyphenols (37). Besides their nutritional properties, Asphodeline species also possess medicinal features and are employed in medical practices in traditional medicine. For instance, A. globifera has been used for alleviating the symptoms of haemorrhoids; $A$. damascena and $A$. cilicica were recorded to be utilized for the treatment of earaches (8); and $A$. lutea has been used for the treatment of skin diseases (9). Due to their mentioned use above, many phytochemical researches have been conducted on Asphodeline species revealing the presence of secondary metabolites such as antraquinones, sesquiterpenes, flavonoids and naphthalene type compounds (6,10-13). Enzymes have very important roles in the pathogenesis of several diseases including cancer, inflammation, Alzheimer's and Parkinson's diseases, familial hypercholesterolemia, myasthenia gravis etc. (14-17). Due to the important roles of these enzymes on several diseases, novel drugs that display inductive or inhibitory effects should be developed.

In the present research, in vitro inhibitory effects of the extracts obtained from the stems, seeds, leaves and roots of $A$. brevicaulis (Bertol.) J. Gay ex Baker subsp. brevicaulis (Bertol.) J. Gay ex Baker var. brevicaulis (Bertol.) J. Gay ex Baker, A. baytopae $\mathrm{E}$. Tuzlacı and $A$. cilicica on hyaluronidase, collagenase and elastase enzymes, which are the major enzymes responsible for dehydration of the skin, were investigated.

\section{EXPERIMENTAL}

Plant materials

Asphodeline species were collected at the end of flowering stage (May-July) and information regarding the collection sites of the plants and herbarium numbers were presented in Table 1. Taxonomic identification of the plant materials were confirmed by the senior taxonomist Dr. Murad Aydın Sanda, from the Department of Biology, Selçuk University. The voucher specimens were deposited at the KNYA Herbarium of Department of Biology, Selçuk University, Konya, Turkey.

\section{Preparation of the plant extracts}

The plant materials (stem, root, seed and leaf) were dried at the room temperature. The dried parts were ground to a fine powder using a laboratory mill. For each of the powdered parts (10 g) were separately extracted with $250 \mathrm{~mL}$ acetone and methanol in a Soxhlet apparatus for 6-8 h. The residue was extracted with $250 \mathrm{~mL}$ hot distilled water for $30 \mathrm{~min}$ and the extracts were filtered concentrated under vacuum at $40^{\circ} \mathrm{C}$ by using a rotary evaporator. The aqueous extracts were lyophilized $\left(-80^{\circ} \mathrm{C}, 48 \mathrm{~h}\right)$. Yields of the extracts were given in Table 1.

\section{In vitro enzyme inhibitory assays}

Hyaluronidase inhibiton assay

Hyaluronidase inhibiton assay was performed according to the methods described by Lee \& Choi (1999) and Sahasrabudhe \& Deodhar (2010) with some modifications (18-20).

An amount of $50 \mu \mathrm{L}$ an aliquot of bovine hyaluronidase (7900 units $/ \mathrm{mL}$ ) was dissolved in $0.1 \mathrm{M}$ acetate buffer $(\mathrm{pH}$ 3.6). This mixture then was mixed with $50 \mu \mathrm{L}$ of different concentrations of the extracts prepared in 5\% DMSO. An aliquot of $50 \mu \mathrm{L}$ of $5 \%$ DMSO was added instead of the extracts in the control group. After incubation at $37^{\circ} \mathrm{C}$ for $20 \mathrm{~min}, 50 \mu \mathrm{L}$ of calcium chloride $(12.5 \mathrm{mM})$ was added to the mixture and reincubated for another 20 minutes at $37^{\circ} \mathrm{C}$. $250 \mu \mathrm{L}$ sodium hyaluronate $(1.2 \mathrm{mg} / \mathrm{mL})$ was added and incubated for 40 minutes at $37^{\circ} \mathrm{C}$.

Table 1. The collection cites and herbarium numbers of Asphodeline species; parts used for the extraction, extract types and percentage yields of the extracts

\begin{tabular}{|c|c|c|c|c|c|}
\hline Plant name & Collection site & Herbarium no & Extract type & Parts used & Yield (w/w, \%) \\
\hline \multirow{2}{*}{ A. brevicaulis subsp. brevicaulis var. brevicaulis } & \multirow{2}{*}{$\begin{array}{l}\text { Mersin, Arslanköy, between Ar- } \\
\text { slanköy and Yeniköy, } 37^{\circ} 00^{\prime} 20.9^{\prime \prime} \mathrm{N} \text {, } \\
34^{\circ} 29^{\prime} 24.6 \text { E, alt. } 1077 \mathrm{~m}\end{array}$} & \multirow{2}{*}{ KNYA-GZ1004 } & Acetone & \multirow{2}{*}{$\mathrm{Sm} / \mathrm{R} / \mathrm{Lf} / \mathrm{Sd}$} & $\begin{array}{l}1.73 / 1.28 / 2.71 / \\
3.91\end{array}$ \\
\hline & & & Aqueous & & $\begin{array}{l}18.05 / 14.1 / \\
20.35 / 20.41\end{array}$ \\
\hline \multirow[b]{2}{*}{ A. baytopae } & \multirow[b]{2}{*}{$\begin{array}{l}\text { Mersin, Gulnar, between Gulnar and } \\
\text { Aydincik, } 36^{\circ} 16^{\prime} 07^{\prime \prime} \mathrm{N}, 33^{\circ} 22^{\prime} 11^{\prime \prime} \mathrm{E}, \\
\text { alt. } 751 \mathrm{~m}\end{array}$} & \multirow[b]{2}{*}{ KNYA-GZ1003 } & Acetone & \multirow[b]{2}{*}{$\mathrm{Sm} / \mathrm{R} / \mathrm{Lf} / \mathrm{Sd}$} & $\begin{array}{l}0.88 / 4.68 / 2.66 / \\
2.71\end{array}$ \\
\hline & & & Methanol & & $\begin{array}{l}4,16 / 39.06 / \\
22.38 / 6.42\end{array}$ \\
\hline \multirow{3}{*}{ A. cilicica } & \multirow{3}{*}{$\begin{array}{l}\text { Adana, between Catalan and Aladag, } \\
37^{\circ} 27^{\prime} 37^{\prime \prime} \mathrm{N}, 35^{\circ} 20^{\prime} 12^{\prime \prime} \mathrm{E} \text {, alt. } 1080 \\
\mathrm{~m}\end{array}$} & \multirow{3}{*}{ KNYA-GZ1005 } & Acetone & \multirow{3}{*}{$\mathrm{Sm} / \mathrm{R} / \mathrm{Lf} / \mathrm{Sd}$} & $\begin{array}{l}2.88 / 2.42 / 4.07 / \\
3.52\end{array}$ \\
\hline & & & Methanol & & $\begin{array}{l}8.85 / 7.39 / 13.32 / \\
14.47\end{array}$ \\
\hline & & & Aqueous & & $\begin{array}{l}10.78 / 9.35 / \\
13.04 / 24.49\end{array}$ \\
\hline
\end{tabular}


Table 2. Collagenase and elastase inhibitory activity of the extracts of Asphodeline species

\begin{tabular}{|c|c|c|c|c|c|}
\hline Material & $\begin{array}{l}\text { Parts } \\
\text { used }\end{array}$ & $\begin{array}{l}\text { Extract } \\
\text { type }\end{array}$ & $\begin{array}{l}\text { Concentration } \\
(\mu \mathrm{g} / \mathrm{mL})\end{array}$ & $\begin{array}{l}\text { Collagnease } \\
\text { inhibition (\%) } \\
\pm \text { S.E.M. }\end{array}$ & $\begin{array}{l}\text { Elastase } \\
\text { inhibition (\%) } \\
\pm \text { S.E.M. }\end{array}$ \\
\hline \multirow{12}{*}{$\begin{array}{l}\text { A. brevicaulis } \\
\text { subsp. brevicaulis } \\
\text { var. brevicaulis }\end{array}$} & \multirow{3}{*}{ Stem } & Acetone & 100 & $15.79 \pm 1.83$ & $19.43 \pm 1.95$ \\
\hline & & Methanol & 100 & $14.66 \pm 1.48$ & $12.63 \pm 1.59$ \\
\hline & & Aqueous & 100 & $15.99 \pm 1.64$ & $19.47 \pm 1.93$ \\
\hline & \multirow{3}{*}{ Seed } & Acetone & 100 & $13.44 \pm 2.14$ & $8.12 \pm 1.66$ \\
\hline & & Methanol & 100 & $17.06 \pm 1.64$ & $16.42 \pm 1.82$ \\
\hline & & Aqueous & 100 & $14.73 \pm 2.14$ & $10.17 \pm 2.34$ \\
\hline & \multirow{3}{*}{ Leaf } & Acetone & 100 & $31.38 \pm 1.14^{* *}$ & $39.39 \pm 1.61^{* *}$ \\
\hline & & Methanol & 100 & $10.93 \pm 2.26$ & $8.37 \pm 2.11$ \\
\hline & & Aqueous & 100 & $8.66 \pm 1.22$ & $6.30 \pm 1.82$ \\
\hline & \multirow{3}{*}{ Root } & Acetone & 100 & $20.34 \pm 2.42$ & $22.49 \pm 2.22$ \\
\hline & & Methanol & 100 & $23.64 \pm 2.31$ & $28.78 \pm 1.98$ \\
\hline & & Aqueous & 100 & $14.38 \pm 1.91$ & $15.85 \pm 1.80$ \\
\hline \multirow{12}{*}{ A. baytopae } & \multirow{3}{*}{ Stem } & Acetone & 100 & $19.31 \pm 2.64$ & $25.46 \pm 1.64$ \\
\hline & & Methanol & 100 & $13.43 \pm 2.54$ & $20.10 \pm 1.76$ \\
\hline & & Aqueous & 100 & $7.56 \pm 1.48$ & $9.29 \pm 1.84$ \\
\hline & \multirow{3}{*}{ Seed } & Acetone & 100 & $30.55 \pm 1.28^{* *}$ & $40.22 \pm 1.46 * *$ \\
\hline & & Methanol & 100 & $37.22 \pm 1.40 * * *$ & $42.32 \pm 1.76^{\star *}$ \\
\hline & & Aqueous & 100 & $9.53 \pm 1.82$ & $11.83 \pm 1.80$ \\
\hline & \multirow{3}{*}{ Leaf } & Acetone & 100 & $16.33 \pm 1.77$ & $18.29 \pm 1.85$ \\
\hline & & Methanol & 100 & $18.89 \pm 1.82$ & $21.16 \pm 2.34$ \\
\hline & & Aqueous & 100 & $8.46 \pm 2.54$ & $9.68 \pm 1.49$ \\
\hline & \multirow{3}{*}{ Root } & Acetone & 100 & $31.70 \pm 1.56^{* *}$ & $41.51 \pm 1.40$ ** \\
\hline & & Methanol & 100 & $29.85 \pm 2.49^{\star}$ & $31.88 \pm 1.92^{*}$ \\
\hline & & Aqueous & 100 & $10.36 \pm 1.99$ & $14.87 \pm 1.55$ \\
\hline \multirow{12}{*}{ A. cilicica } & \multirow{3}{*}{ Stem } & Acetone & 100 & $12.26 \pm 2.83$ & $14.64 \pm 1.72$ \\
\hline & & Methanol & 100 & $9.41 \pm 1.34$ & $7.84 \pm 1.90$ \\
\hline & & Aqueous & 100 & $35.38 \pm 1.43^{* * *}$ & $45.97 \pm 1.44^{* *}$ \\
\hline & \multirow{3}{*}{ Seed } & Acetone & 100 & $16.66 \pm 2.04$ & $20.66 \pm 1.89$ \\
\hline & & Methanol & 100 & $15.36 \pm 1.92$ & $18.54 \pm 2.34$ \\
\hline & & Aqueous & 100 & $8.52 \pm 1.78$ & $9.44 \pm 1.62$ \\
\hline & \multirow{3}{*}{ Leaf } & Acetone & 100 & $36.71 \pm 1.21^{\star *}$ & $43.32 \pm 1.58^{\star *}$ \\
\hline & & Methanol & 100 & $34.22 \pm 1.49^{* *}$ & $47.42 \pm 1.41^{* *}$ \\
\hline & & Aqueous & 100 & $8.33 \pm 1.63$ & $13.83 \pm 1.63$ \\
\hline & \multirow{3}{*}{ Root } & Acetone & 100 & $37.61 \pm 1.73^{* * *}$ & $48.44 \pm 1.53^{* *}$ \\
\hline & & Methanol & 100 & $39.90 \pm 1.15^{\star \star \star}$ & $53.78 \pm 1.33^{* *}$ \\
\hline & & Aqueous & 100 & $28.77 \pm 1.70^{*}$ & $30.15 \pm 1.70^{*}$ \\
\hline $\begin{array}{l}\text { Epigallocathecin } \\
\text { gallate }\end{array}$ & & & 100 & $48.62 \pm 1.14^{\star \star *}$ & $84.31 \pm 1.24^{* * *}$ \\
\hline
\end{tabular}

${ }^{*}: p<0.05 ;{ }^{* *}: p<0.01 ;{ }^{* *}$ : $p<0.001 ;$ S.E.M.: Standard error of the mean
The mixture was treated with $50 \mu \mathrm{L}$ of $0.4 \mathrm{M} \mathrm{NaOH}$ and 100 $\mu \mathrm{L}$ of $0.2 \mathrm{M}$ sodium borate and then incubated for $3 \mathrm{~min}$ in the boiling water. $p$-Dimethylaminobenzaldehyde solution $(1.5 \mathrm{~mL})$ was added to the reaction mixture after cooling to room temperature and was further incubated at $37^{\circ} \mathrm{C}$ for 20 minutes to develop a color. The absorbance of this colored solution was measured at $585 \mathrm{~nm}$ by using Beckmann Dual Spectrometer (Beckman, Fullerton, CA, USA).

\section{Collagenase inhibiton assay}

The method for the collagenase inhibition was performed according to the method of Barrantes \& Guinea (2003) with some modifications $(20,21)$.

The samples were dissolved in DMSO. Clostridium histolyticum (ChC) was dissolved in $50 \mathrm{mM}$ Tricine buffer (with $0.4 \mathrm{M} \mathrm{NaCl}$ and 0.01M CaCl, $\mathrm{pH}$ 7.5). Then, 2 mM N-[3-(2-Furyl)acryloyl]Leu-Gly-Pro-Ala (FALGPA) solution was prepared in the same buffer. $25 \mu \mathrm{L}$ buffer, $25 \mu \mathrm{L}$ test sample and $25 \mu \mathrm{L}$ enzyme were added to each well and incubated for 15 minutes. $50 \mu \mathrm{L}$ substrate was added into the mixture. The decrease of the optical density (OD) was immediately measured at $340 \mathrm{~nm}$ using a spectrophotometer.

The ChC inhibitory activity of each sample was calculated according to the following formula:

$\mathrm{ChC}$ inhibition activity $(\%)=O D_{\text {Control }}-O D_{\text {Sample }} \times 100 / O D_{\text {Control }}$ where $O D_{\text {control }}$ and $O D_{\text {sample }}$ represent the optical densities in the absence and presence of sample, respectively.

\section{Elastase inhibiton assay}

According to the method described by Melzig et al. (2001), the sample solution and human neutrophil elastase enzyme (HNE) $(17 \mathrm{mU} / \mathrm{mL}$ ) were mixed in $0.1 \mathrm{M}$ Tris- $\mathrm{HCl}$ buffer $(\mathrm{pH}$ 7.5). The mixture was incubated at $25^{\circ} \mathrm{C}$ for $5 \mathrm{~min}$. N-MethoxysuccinylAla-Ala-Pro-Val $p$-nitroanilide (MAAPVN) was added into the mixture and incubated at $37^{\circ} \mathrm{C}$ for $1 \mathrm{~h}$. By the addition of 1 $\mathrm{mg} / \mathrm{mL}$ soybean trypsin inhibitor, the reaction was stopped and the optical density was immediately measured at $405 \mathrm{~nm}$. The HNE inhibitory activities were calculated according to the equation given in the ChC inhibitory assay $(20,22)$.

\section{Statistical analysis of the data}

The data was statistically analyzed using one-way analysis of variance (ANOVA). The values of $p \leq 0.05$ were considered statistically significant.

\section{RESULTS}

Turkey is considered as one of the gene centers of Asphodeline genus with 20 taxa, as it is represented in Europe by only three species. Plants of the genus Asphodeline have traditionally been used as either food or therapeutical agent in various parts of the world as well as in Turkey $(1,2)$. In the previous study, Asphodeline species were found to possess acetylcholinesterase, butyrylcholinesterase, amylase, glucosidase and tyrosinase inhibitory activities (3). Indeed, enzymes are known to be involved in the pathogenesis of several diseases, for instance hyaluronidase, collagenase and elastase enzymes involves in the pathogenesis of wound, cancer, cardiovascular diseases, inflammation, bone destruction and fibrosis $(20,23-$ 26). Collagen and elastin are the major components of the connective tissue and hyaluronic acid keeps the moist. 
Table 3. Hyaluronidase inhibitory activity of the extracts of

Asphodeline species

\begin{tabular}{|c|c|c|c|c|}
\hline Material & $\begin{array}{l}\text { Parts } \\
\text { used }\end{array}$ & $\begin{array}{l}\text { Extract } \\
\text { type }\end{array}$ & $\begin{array}{l}\text { Concentration } \\
(\mu \mathrm{g} / \mathrm{mL})\end{array}$ & $\begin{array}{l}\text { Hyaluronidase } \\
\text { inhibition (\%) } \pm \\
\text { S.E.M. }\end{array}$ \\
\hline \multirow{12}{*}{$\begin{array}{l}\text { A. brevicaulis } \\
\text { subsp. brevicaulis } \\
\text { var. brevicaulis }\end{array}$} & \multirow{3}{*}{ Stem } & Acetone & 100 & $20.16 \pm 1.42$ \\
\hline & & Methanol & 100 & $15.72 \pm 1.93$ \\
\hline & & Aqueous & 100 & $14.78 \pm 2.16$ \\
\hline & \multirow{3}{*}{ Seed } & Acetone & 100 & $20.16 \pm 1.42$ \\
\hline & & Methanol & 100 & $15.72 \pm 1.93$ \\
\hline & & Aqueous & 100 & $14.78 \pm 1.46$ \\
\hline & \multirow{3}{*}{ Leaf } & Acetone & 100 & $21.49 \pm 1.32$ \\
\hline & & Methanol & 100 & $15.72 \pm 1.93$ \\
\hline & & Aqueous & 100 & $14.78 \pm 2.16$ \\
\hline & \multirow{3}{*}{ Root } & Acetone & 100 & $27.55 \pm 1.82$ \\
\hline & & Methanol & 100 & $28.12 \pm 1.74$ \\
\hline & & Aqueous & 100 & $14.39 \pm 1.44$ \\
\hline \multirow{12}{*}{ A. baytopae } & \multirow{3}{*}{ Stem } & Acetone & 100 & $27.48 \pm 2.69$ \\
\hline & & Methanol & 100 & $12.64 \pm 1.81$ \\
\hline & & Aqueous & 100 & $7.74 \pm 1.21$ \\
\hline & \multirow{3}{*}{ Seed } & Acetone & 100 & $29.95 \pm 1.86$ \\
\hline & & Methanol & 100 & $28.67 \pm 1.72$ \\
\hline & & Aqueous & 100 & $10.46 \pm 2.18$ \\
\hline & \multirow{3}{*}{ Leaf } & Acetone & 100 & $22.83 \pm 1.39$ \\
\hline & & Methanol & 100 & $28.37 \pm 2.66$ \\
\hline & & Aqueous & 100 & $18.53 \pm 2.28$ \\
\hline & \multirow{3}{*}{ Root } & Acetone & 100 & $35.14 \pm 1.44^{*}$ \\
\hline & & Methanol & 100 & $18.22 \pm 1.93$ \\
\hline & & Aqueous & 100 & $13.82 \pm 2.94$ \\
\hline \multirow{12}{*}{ A. cilicica } & \multirow{3}{*}{ Stem } & Acetone & 100 & $17.26 \pm 1.95$ \\
\hline & & Methanol & 100 & $9.50 \pm 1.38$ \\
\hline & & Aqueous & 100 & $45.51 \pm 1.25^{\star *}$ \\
\hline & \multirow{3}{*}{ Seed } & Acetone & 100 & $32.29 \pm 2.12$ \\
\hline & & Methanol & 100 & $16.23 \pm 2.19$ \\
\hline & & Aqueous & 100 & $12.21 \pm 1.63$ \\
\hline & \multirow{3}{*}{ Leaf } & Acetone & 100 & $39.26 \pm 1.11^{* *}$ \\
\hline & & Methanol & 100 & $42.30 \pm 1.14^{\star *}$ \\
\hline & & Aqueous & 100 & $16.48 \pm 1.86$ \\
\hline & \multirow{3}{*}{ Root } & Acetone & 100 & $47.20 \pm 1.01^{* *}$ \\
\hline & & Methanol & 100 & $49.49 \pm 1.17^{\star *}$ \\
\hline & & Aqueous & 100 & $25.14 \pm 1.81$ \\
\hline Tannic acid & & & 100 & $87.33 \pm 0.94^{\star * *}$ \\
\hline
\end{tabular}

${ }^{*}: p<0.05 ;{ }^{* *}: p<0.01 ;{ }^{* *}:$ p<0.001; S.E.M.: Standard error of the mean
Inhibition of hyaluronidase, collagenase and elastase enzymes could therefore improve skin aging (20,27-29). In the present study we aimed to investigate in vitro inhibitory effects of the extracts prepared from the different parts of $A$. baytopae, A. brevicaulis subsp. brevicaulis var. brevicaulis, A. cilicica on hyaluronidase, collagenase and elastase enzymes.

The results revealed that the methanol extract prepared from the roots of $A$. cilicica (ACRM) displayed the highest hyaluronidase, collagenase and elastase inhibitory activity with the inhibition value of $49.49 \%, 39.90 \%$ and $53.78 \%$, respectively. It was also found that acetone extract of the roots of $A$. cilicica (ACRAc) demonstrated $37.61 \%$ and $48.44 \%$ inhibitiory effect on collagenase and elastase enzymes, respectively. In addition, acetone extract of the leaves of A. brevicaulis subsp. brevicaulis var. brevicaulis ( $\mathrm{BBr} \mathrm{Ac}$ ) demonstrated inhibitiory effect with the values of $31.38 \%$ and $39.39 \%$ on collagenase and elastase enzymes, respectively. Acetone and methanol extracts of the seeds of $A$. baytopae ( $A B a S d A c$ and $A B a S d M$ ), acetone and methanol extracts of the roots of $A$. baytopae ( $A B a R A c$ and $A B a R M)$, aqueous extract of the stems of $A$. cilicica ( $A C S m A q$ ), acetone and methanol extracts of the leaves of $A$. cilicica (ACLAc and ACLM), aqueous extract of the roots of $A$. cilicica (ACRAq) possessed significant collagenase and elastase inhibitory activities. On the other hand, ABaRAc, ACSmAq, ACLAc, ACLM and ACRAc were detected to possess significant hyaluronidase inhibitory effect (Table 2 and 3).

\section{DISCUSSION}

According to the ethnobotanical studies, Asphodeline species such as $A$. cilicica, $A$. damascena, A. globifera, A. lutea, and A. taurica are consumed as food in salads (4). Due to the information regarding its consumption as food, the nutritional features of these species were investigated in our previous research revealing their high amount amino acid composition (4). Asphodeline species are used not only as food, but also as therapeutic agents for earaches, skin disorders and haemorrhoids in folk medicine $(8,9,13)$. Due to their several medicinal utilization by people living in rural areas, Asphodeline species recently have attracted the researchers' attention to either verify the therapeutical usage in scientific platform or to investigate the phytochemical ingredients.

There have been several studies indicating the enzyme inhibitory activities of phenolic compounds and anthraquinones. Sawabe et al. (1998) investigated the inhibitory effects of water extracts obtained from sixty-six natural medicines on hyaluronidase, elastase and tyrosinase enzymes. The study pointed out that the enzyme inhibitory effect is positively correlated with high amount of phenolic content (30). Moreover, Lee et al. (2001) isolated a new phenolic compound, encoded CC-517, from Areca catechu L. and revealed its significant anti-hyaluronidase and anti-elastase activities. The compound inhibited human neutrophil elastase with the $\mathrm{IC}_{50}$ value of $60.8 \mu \mathrm{g} / \mathrm{mL}$; hyaluronidase with the $\mathrm{IC}_{50}$ value of $210 \mu \mathrm{g} / \mathrm{mL}$. It also exhibited more potent elastase inhibitory effect than oleanolic acid and ursolic acid (31).

Tanaka et al. (1990) conducted a study on collagenase inhibitory effect of 44 anthraquinone type compounds. Results of the 
study demonstrated the inhibitory activity of anthraquinones, amongst emodin being the most potent active inhibitor with the $I C_{50}$ value of $4 \times 10^{-5} \mathrm{M}$ (32). Furthermore, Zembower et al. (1992) synthesized several anthraquinone analogues and evaluated their elastase inhibitory activity on human leukocyte. Consequently, it was reported that 1,8 dihydroxyanthraquinone analogues possess elastase inhibitory effect (33).

Previous researches reported that Asphodeline species have high antioxidant capacity and phenolic content (7,13,34). Similarly, Zengin et al. (2015) recently investigated the antioxidant and enzyme inhibitory effects as well as anthraquinone profile of the methanol extracts obtained from the roots of eight Asphodeline species. According to the results, A. cilicica was found to possess the highest total phenolic content, while A. brevicaulis subsp. brevicaulis var. brevicaulis and $A$. baytopae had the highest total anthraquinone content. Therefore, the inhibitory effects of $A$. cilicica, $A$. brevicaulis subsp. brevicaulis var. brevicaulis and $A$. baytopae could be attributed to its phenolic and anthraquinone contents (3).

\section{CONCLUSION}

In the present study, ACRM, ACRAc, ABrLAc, ABaSdAc, ABaSdM, $A B a R A c, A B a R M, A C S m A q, A C R A q$ significantly inhibited collagenase, elastase and hyaluronidase enzymes, suggesting that these extracts could be used for the treatment of several diseases including wound, cancer, cardiovascular diseases, inflammation, bone destruction and fibrosis as well as potential ingredients for the cosmetic formulations to avoid skin aging.

\section{REFERENCES}

1. Mathews VA, Tuzlaci E, Asphodeline Reichb. In: Flora of Turkey and East Aegean Islands, Ed(s): P.H. Davis, pp. 88-97, University Press, Edinburgh, 1984.

2. Tuzlaci E, Revision of the genus Asphodeline (Liliaceae). A new infrageneric classification, Candollea 42, 559-576, 1987.

3. Zengin G, Locatelli M, Ceylan R, Aktumsek A, Anthraquinone profile, antioxidant and enzyme inhibitory effect of root extracts of eight Asphodeline taxa from Turkey: Can Asphodeline roots be considered as a new source of natural compounds?, J Enzyme Inhib Med Chem 1-6, 2015.

4. Zengin G, Aktumsek A, Guler GO, Cakmak YS, Giron-Calle J, Alaiz $M$, Vioque J, Nutritional quality of protein in the leaves of eleven Asphodeline species (Liliaceae) from Turkey., Food Chem 135, 13601364, 2012.

5. Lazarova I, Marinova E, Todorova-Nikolova G, Kostova I, Antioxidant properties of Asphodeline lutea of Bulgarian origin, Riv Ital Sostanze Gr 86, 181-188, 2009.

6. Todorova G, Lazarova I, Mikhova B, Kostova I, Anthraquinone, naphtalene, and napthoquinone components of Asphodeline lutea, Chem Nat Compd 46, 322-323, 2010.

7. Lazarova I, Zengin G, Aktumsek A, Gevrenova R, Ceylan R, Uysal S, HPLC-DAD analysis of phenolic compounds and antioxidant properties of Asphodeline lutea roots from Bulgaria and Turkey, Ind Crops Prod 61, 438-441, 2014.

8. Tuzlaci E, Çiriş plants of Turkey, J Pharm Marmara 1, 69-89, 1985.

9. Ali-Shtayeh MS, Yaniv Z, Mahajna J, Ethnobotanical survey in the Palestinian area: A classification of the healing potential of medicinal plants, J Ethnopharmacol 73, 221-232, 2000.

10. Ulubelen A, Tuzlaci E, Sesquiterpene lactones, flavonoids and anthraquinones from Asphodeline globifera and Asphodeline damascena, Phytochemistry 24, 2923-2924, 1985.

11. Ulubelen A, Terem B, Tuzlaci E, Antraquinones and sesquiterpene lactones from Asphodeline anatolica, Fitoterapia 2, 159, 1988.
12. Ulubelen A, Tuzlaci E, Atılan N, Antraquinones and sesquiterpene lactones from Asphodeline anatolica, Fitoterapia 2, 159, 1989.

13. Zengin G, Aktumsek A, Investigation of antioxidant potentials of solvent extracts from different anatomical parts of Asphodeline anatolica E. Tuzlaci: An endemic plant to Turkey, Afr J Tradit Complement Altern Med 11, 481-488, 2014.

14. Kolins J, Gilroy J, Serum enzyme levels in patients with myasthenia gravis afte aerobic and ischaemic exercise, J Neurol Neurosurg Psychiatry 35, 34-40, 1972.

15. Goldstein JL, Brown MS, Familial hypercholesterolemia: identification of a defect in the regulation of 3-hydroxy-3-methylglutaryl coenzyme A reductase activity associated with overproduction of cholesterol, Proc Natl Acad Sci U S A 70, 2804-2808, 1973.

16. Goldstein $M$, Lieberman $A$, The role of the regulatory enzymes of catecholamine synthesis in Parkinson's disease, Neurology 42, 8-12, 1992.

17. Cole SL, Vassar R, The Alzheimer's disease beta-secretase enzyme, BACE1, Mol Neurodegener 2, 22, 2007.

18. Lee KK, Choi JD, The effects of Areca catechu L extract on anti-aging, Int J Cosmet Sci 21, 285-295, 1999.

19. Sahasrabudhe A, Deodhar M, Anti-hyaluronidase, anti-elastase activity of Garcinia indica, Int J Bot 6, 299-303, 2010.

20. Suntar I, Kupeli Akkol E, Keles H, Yesilada E, Sarker SD, Arroo R, Baykal T, Efficacy of Daphne oleoides subsp. kurdica used for wound healing: identification of active compounds through bioassay guided isolation technique, J Ethnopharmacol 141, 1058-1070, 2012.

21. Barrantes $E$, Guinea $M$, Inhibition of collagenase and metalloproteinases by aloins and aloe gel, Life Sci 72, 843-850, 2003.

22. Melzig MF, Loser B, Ciesielski S, Inhibition of neutrophil elastase activity by phenolic compounds from plants, Pharmazie 56, 967-970, 2001.

23. Girish KS, Kemparaju K, Nagaraju S, Vishwanath BS, Hyaluronidase inhibitors: A biological and therapeutic perspective, Curr Med Chem 16, 2261-2288, 2009.

24. Alam SR, Newby DE, Henriksen PA, Role of the endogenous elastase inhibitor, elafin, in cardiovascular injury: from epithelium to endothelium, Biochem Pharmacol 83, 695-704, 2012.

25. Moroy G, Alix AJ, Sapi J, Hornebeck W, Bourguet E, Neutrophil elastase as a target in lung cancer, Anticancer Agents Med Chem 12, 565-579, 2012.

26. Kumar V, Abbas AK, Aster JC, Robbins SL, Robbins basic pathology. 9th ed. Philadelphia, Elsevier, 2013.

27. Demina NS, Lysenko SV, Collagenolytic enzymes synthesized by microorganisms, Mikrobiologiia 65, 293-304, 1996.

28. Thring TS, Hili P, Naughton DP, Anti-collagenase, anti-elastase and anti-oxidant activities of extracts from 21 plants, BMC Complement Altern Med 9, 27, 2009.

29. Abdul Wahab N, Abdul Rahman R, Ismail A, Mustafa S, Hashim P, Assessment of antioxidant capacity, anti-collagenase and antielastase assays of Malaysian unfermented cocoa bean for cosmetic application, Nat Prod Chem Res 2, 2014.

30. Sawabe Y, Yamasaki K, Iwagami S, Kajimura K, Nakagomi K, Inhibitory effects of natural medicines on the enzymes related to the skin, Yakugaku Zasshi 118, 423-429, 1998.

31. Lee KK, Cho JJ, Park EJ, Choi JD, Anti-elastase and anti-hyaluronidase of phenolic substance from Areca catechu as a new anti-ageing agent, Int J Cosmet Sci 23, 341-346, 2001.

32. Tanaka T, Metori K, Mineo S, Matsumoto H, Satoh T, Studies on collagenase inhibitors. II. Inhibitory effects of anthraquinones on bacterial collagenase., Yakugaku Zasshi 110, 688-692, 1990.

33. Zembower DE, Kam CM, Powers JC, Zalkow LH, Novel anthraquinone inhibitors of human leukocyte elastase and cathepsin G, J Med Chem 35, 1597-1605, 1992.

34. Atasü E, Flavonoids of Asphodeline lutea Reichb. flowers, J Fac Pharm Ankara 10, 102-111, 1980.

Received : 17.03.2016

Accepted : 18.03.2016 